\title{
Determining the Yield and the Quality Paramaters for Some Local Pea (Pisum sativum L.) Varieties in Eastern Mediterranean Region
}

\author{
Dürdane Mart ${ }^{1, *}$, Meltem Türkeri ${ }^{1}$, Derya Yücel $^{2}$, Sezgin Mart ${ }^{3}$ \\ ${ }^{1}$ East Mediterranean Agricultural Research Institute, Doğankent, Adana, Turkey. \\ ${ }^{2}$ Faculty of Agricultural, Sirnak University, Şirnak, Turkey. \\ ${ }^{3}$ Faculty of Crop Sciences, Hohenheim University, Stuttgart, Germany.
}

How to cite this paper: Dürdane Mart, Meltem Türkeri, Derya Yücel, Sezgin Mart. (2021) Determining the Yield and the Quality Paramaters for Some Local Pea (Pisum sativum L.) Varieties in Eastern Mediterranean Region. International Journal of Food Science and Agriculture, 5(3), 350-354.

DOI: $10.26855 /$ ijfsa.2021.09.002

Received: May 24, 2021

Accepted: June 22, 2021

Published: July 5, 2021

*Corresponding author: Dürdane Mart, Eastern Mediterranean Agricultural Research Institute, Turkey.

Email: durdanemart@yahoo.com

\begin{abstract}
This research was carried out to determine the seed yield and quality components of some pea genotypes under eastern mediterranean ecological conditions during 2015 and 2016 at East Mediterranean Agricultural Research Institute, Adana location. Research was conducted with different local pea populations, pea vareties from ICARDA and from Menemen gene bank under Eastern Mediterranean conditions for pea variety breeding. Trials were investigated under winter conditions. The area of the research was located between the geographic latitudes of $36^{0} 51^{\prime} 17.21$ North and $35^{\circ} 20^{\prime} 41.61$ East with an altitude of $23 \mathrm{~m}$. According to the results of the analyses from this study, the highest and the lowest values are following, 273.6-142.2 kg/da for the yield, 57-38 days for the flowering time, 121.0-62.7 $\mathrm{cm}$ for the plant height, 28.4-15.1 gr for the 100-grain weight in the winter sowing conditions. In addition to these, the highestand the lowest protein content were 31.84-26.26. Pea has an important place in human and animal nutrition with its rich nutritional content. These results provide an initial step for the development of promising Pisum sativum L. varieties in sustainable breeding programs.
\end{abstract}

\section{Keywords}

Pea, Yield, Quality, Genotype

\section{Introduction}

Peas (Pisum sativum L.) are important leguminous plant used as a food source of human as well as being an animal feed worldwide owing to its high protein content of 20-30\%. As a leguminous plant, pea transforms the free nitrogen in the air into a form that plants can take, it contains sufficant level of carbohydrates; rich in calcium, iron and especially phosphorus and it is also a good source of vegetable protein in terms of having various vitamins [1-2]. Turkey is a motherland ofmany leguminous plants including peas (Pisum sativum L.). Peas were originated mainly in Eastern-Mediterranean, Iran and between Caucasusand Tibet [3-6]. For the origanation of peas, Watts and Watts (1954) was mentioned that Ethiopia, Mediterranean sides, South-West Asia on the other hand, [7] stated that Mediterranean countries and Ethiopia are the centers that pea spreaded into the world. Peas, which can be grown in almost every region of Turkey, are the most commonly used ingredient in the canned food industry and in the community. It is one of the most important raw materials of the canned and frozen food industry, the straw of pea is also used for animal feding.

Having an important place in human and animal nutrition with its rich nutritional content, pea is the fourth place after chickpeas, lentils and beans in terms of sowing area and production in [8]. According to the statistics of the year 2021 in our country, total pea cultivation area is about 781 ha, production is 2.193 tons and the yield is $28.079 \mathrm{hg} / \mathrm{ha}$ [8]. Peas farming in our country is carried out mostly in the production of fresh peas especially in the coastal areas (Marmara, 
Aegean and Mediterranean regions in particular).

The development of varieties with high yields, desired characteristics for domestic consumption and exporting and the application of the cultivation techniques which will reveal these characteristics are very important for the presentation of pure and high quality product for the market, for feeding our people and for exporting [9].

Pea is a very important plant as an intermediate product in the cultivation of field crops. Peas are very important crops as an intermediary product in terms of giving the opportunity to the following crop to be treated as a main crop due tothe cultivation of peas during winter in the Mediterranean Region and leaving the field in the early period.

In many countries around the world, peas are produced in large quantities for consumption as fresh and processed food. It is one of the products that produced for canned and frozen food industry. Pea is one of the leading plants in canned and stuffed vegetable production. Due to the short consumption period of peas, the canned process is very common in both factories and homes. As the pea flour is used in the food industry, especially the plant margin stem and straw are used as animal feed. The varieties of peas that are grown in Turkey can be grouped under three main groups: round seeds, husked/wrinkled seeds and sultani-sweet peas. Round seeded peas from these groups are not preferred in canned food industry due to the formation of sediments in the bottom of the center by converting the sugar into starch during starch processing. Canned peas are being cultivated in the countries where the climate is temperate and both the spring and autumn sowing are possiblethat aims to extend the product processing season of the canning factories [10].

Quality values for pea are very important; especially starch values, which is an important criteria for maintaining the protein values and suitability to canned in the canned food industry. Due to the high quality and quantity of the product, the development of suitable varieties in pea cultivation is an important factor in increasing production and quality. Turkey has rich genetic resources for many cultivated plants, as well as peas. It is important to investigate the pea gene sources in Turkey with different researches in terms of agronomic and quality characteristics and to use them in breeding programs. The new pea lines that generated using the the local gene resources were lead to an increase in quality and quantity of peas [11-12]. The study of agronomic and quality characteristics of these local gene resources which have high ability to adapt to different ecologies and the rapid integration of this material into the pea breeding programs will be very important for the development of new varieties originating in Turkey that suitable for different ecological regions. This research was carried out to develop new varieties of peas which can be grown under winter conditions in Eastern Mediterranean region, having high yield and quality, suitable for machine harvest and tolerant to diseases and insects.

\section{Materials and Methods}

This study contains some pea varieties from the pea breeding program conducted by the Eastern Mediterranean Agricultural Research Institute. The materials are local pea populations collected from various regions of Turkey, from ICARDA Genebank and from Izmir Menemen Genebank. From these populations, single plant selection is made and the lines are purified. In this study, the responses of the varieties in the field conditions and quality values of the advanced lines are investigated. The high quality and quantity lines were determined for breeding studies.

This research was conductedin the field trial locations from The Eastern Mediterranean Agricultural Research Institute (Adana) during the 2015-2016 raising season. The plots were made in 4 rows (parcels of $9 \mathrm{~m}^{2}$ ) with a length of $5 \mathrm{~m}$, with $45 \mathrm{~cm}$ between rows and $10 \mathrm{~cm}$ above the rows. $3.0 \mathrm{~kg} \mathrm{~N}, 6 \mathrm{~kg} \mathrm{P}_{2} \mathrm{O}_{5}$ was fertilized before the sowing. Some important morphological observations were made in each plot.

Table 1. Some Physical and Chemical Properties of Trial Area Soils

Soil Structure Distribution

\begin{tabular}{ccccccccc} 
Sand (\%) & Silt (\%) & Clay (\%) & $\mathrm{pH}(1: 1)$ & Lime (\%) & Org. Mad (\%) & Total salt (\%) & $\mathrm{P}_{2} \mathrm{O}_{5}(\mathrm{~kg} / \mathrm{da})$ \\
\hline 32.0 & 37.7 & 30.3 & 7.43 & 12.0 & 1.3 & 0.2 & 4.1 \\
\hline
\end{tabular}

The Eastern Mediterranean Agricultural Research Institutelocated in Adana/Turkey contains of a class of clayey-brown alluvial soils that are run in the sense that the texture is moderate throughout the profile when the physical and chemical analysis results of the land area are examined (Table 1). Althought the organic matter content was low, the soil was suitable for agricultural use without salinity problem. In areas where the research was originally established, as shown in Table 1, the soil $\mathrm{pH}$ was 7.43 ; the salt level was found to be $0.23 \%$ and the content of lime was found to be 12.0.

The climatic chracteristics during the production period such as monthly rainfall, temperature and relative humidity rates of Adana where the research was conducted can be seen in Table 2. In particular, it is observed that rainfall has not been distributed evenly during the growing seasons especiallythere has been low rainfall according to the average for many years during the plant development periods in November, December, February and April. This uneven distribution of rainfall has had a negative effect on the development of plants. 
Table 2. Climate Data in Adana Province of 2015-16 Growing Year

\begin{tabular}{ccccccc}
\hline \multirow{2}{*}{ Month } & \multicolumn{2}{c}{ Rain (mm) } & \multicolumn{2}{c}{ AverageTemparature C } & \multicolumn{2}{c}{ Moisture (\%) } \\
& Long Years & 2015-2016 & Long Years & 2015-2016 & Long Years & 2015-2016 \\
\hline November & 67.2 & 0 & 15.3 & 13.1 & 63 & 71.6 \\
December & 118.1 & 0 & 11.1 & 9.1 & 66 & 65.5 \\
January & 111.7 & 105 & 9.7 & 7.3 & 66 & 72.4 \\
February & 92.8 & 64 & 10.4 & 12.3 & 66 & 79.2 \\
March & 67.9 & 97.5 & 13.3 & 14.0 & 66 & 70.0 \\
April & 51.4 & 5 & 17.5 & 18.5 & 69 & 73.4 \\
May & 46.7 & 71 & 21.7 & 19.8 & 67 & 70.3 \\
June & 22.4 & 0 & 25.6 & 23.0 & 66 & 83.1 \\
July & 5.4 & 5 & 27.7 & & 68 & \\
Total & 600 & 383.5 & & & & \\
\hline
\end{tabular}

\section{Results and Discussion}

The yield values of the winter peas cultivated in the trial area of Eastern Mediterranean Agricultural Research Institute, Adana during the 2015-2016 growing season are given in Table 3. Adverse effects were detected on yield due to irregular distribution of rainfall amount.

In Table 3, the highest values for grain yield were shown as $273.6 \mathrm{~kg} / \mathrm{da}$ from the Bolero variety; $244.1 \mathrm{~kg} / \mathrm{da}$ from the Antalya 13 variety; and $238.9 \mathrm{~kg} / \mathrm{da}$ fromthe Rondo variety whilethe lowest value was obtained from the Denizli 8 variety which was $130.4 \mathrm{~kg} / \mathrm{da}$. The amount of rainfall was low compared to long years and the distribution was irregular which resulted in low yield. [13-14] were conducted a two year study on some pea lines to identify their suitability and their yield performance under Eastern Mediterranean conditions and found the yield ranged between 238.7-422.3 kg/da for the first year and between 100.7-273.7 kg/da for the second year and between 181.9-309.8 kg/da as an avarage of two year [15-16].

The number of flowering days were ranged between 57-38 days andthe number of days for pod binding varied between 71.3-51.3 days. Plant height values were ranged between 93.8-47.2 cm, the first pod height was between 121.0-62.7 $\mathrm{cm}$ and also it has been determined that the 100-grain weight varied between 28.4-15.1 gr [17]. As quality parameters, the highest and the lowest protein values were found to vary between 30.62-26.33 and starch values between $47.20-28.02 \%$. A wide variation was observed on varieties due to the availability of short and tall plant types due to the fact that the base of our material is the population.

The variation of new resources which is the crucial paramater in sustainable breeding programs is highly limited in peas [17-18]. It is important to develop new varieties of peas with the local pea populations which will contain early maturity, high quality, high yield, resistance to low temperature and drought, which can be adapted to different regions [19]. The negative conditions for the production and export of pea should be solved and new promising projections should be planned. The pea has the least number of local variety number among the edible lugumes in Turkey [20]. There are three registered pea varieties in Turkey for the dry consumption and two of those varieties (Irmak, Deren) were developed by our team in the Eastern Mediterranean Research Institute. The expansion of pea agriculture as a winter intermediate crop in the coastal regions will contribute significantly to the production and consumption of peas in our country. Therefore, the study of these gene sources in our country, rich in pea gene resources, with their agronomic and quality characteristics [21].

Their ability to comply with different ecologies, and their integration into pea breeding programs will be very important and beneficial for the development of local varieties suitable for different ecological zones.

\section{Conclusion}

Pea is also a very important crop in multiple crop/year production types as an intermediate crop. Especially the winter growing of pea in Mediterranean region will allow the following crop to act as a main crop with leaving the field in early period [22]. The studies on the promising lines that are identified as Antalya 13, Konya 155, Antalya 50, Gaziantep 94 will continue further. Turkey is one of the most important gene center for many crop species including field peas. Although, several investigations has been conducted on the Turkish field pea genetic resources, however, there is further need to conduct more research on these genetic resources to evaluate agronomic performance and 
quality traits as well. This will be very crucial to use in effective breeding programe, germplasm collection and as well as in conservation strategies [23]. We continue our efforts to develop high-yielding and high-quality pea varieties that are adaptable to the region, tolerant to diseases, in line with our breeding objectives.

The quality parameters for pea are very important. Especially the starch values has an important role on protein content and suitability for canned food industry.

Table 3. Obtained from 2015-2016 Year Number of Days Pea Genotypes Flowering, Plant Height, 100-Grain Weight, Yield Values

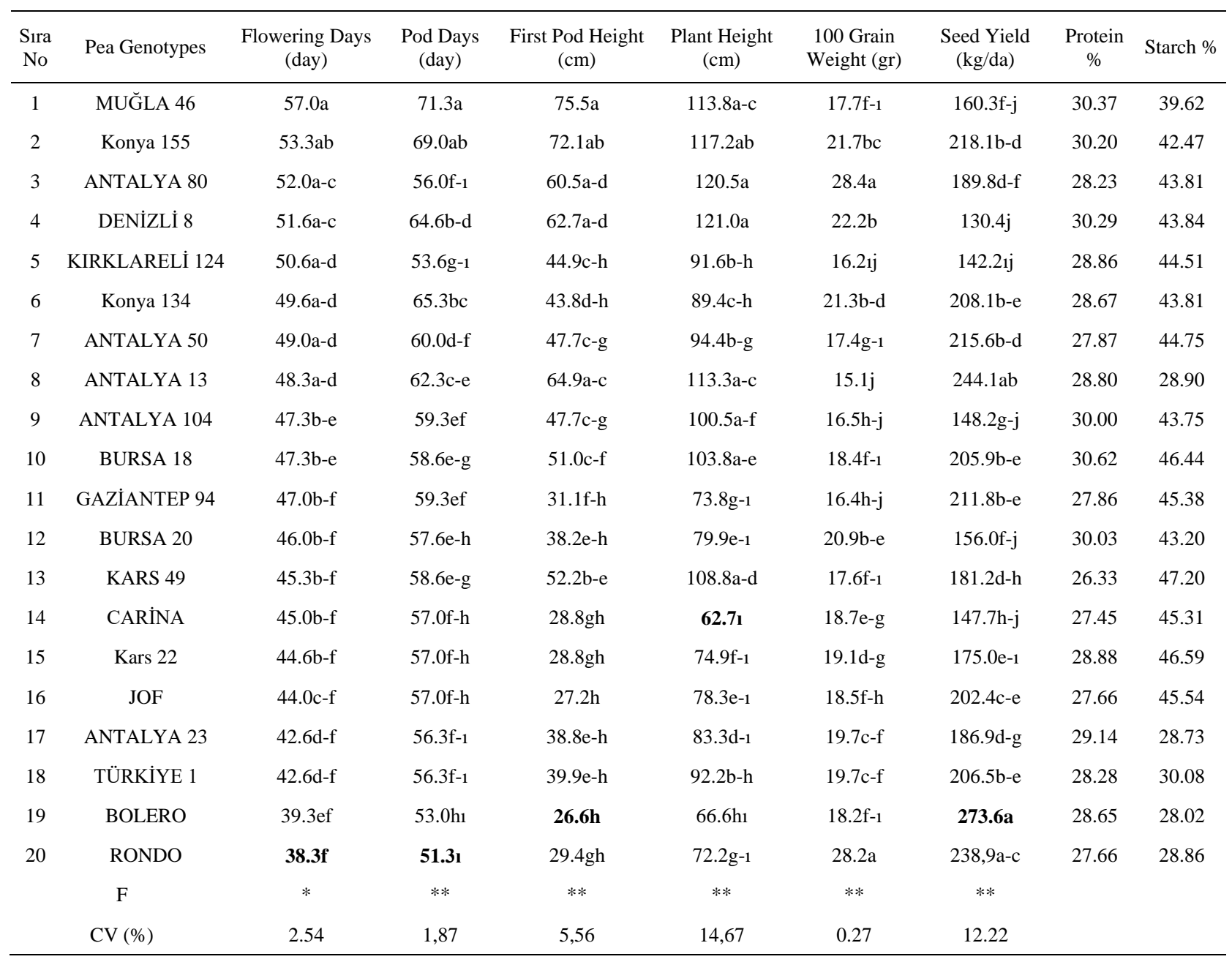

CV: Variation of Cofficient. *: Significant.

\section{References}

[1] Akçin, A. (1988). Food Grain Legumes, Textbook. Selçuk. Üni. publications: 43 Faculty of Agricultural publications 8, 377 Konya Turkey.

[2] Şehirali, S. (1988). Food Grain Legumes, Ankara University Faculty of Agriculture publications, 1089, Ankara, p. 435.

[3] Davies, D. R. (1976). Peas, In: Simmonds N.W. (ed), volution of crop plants. Longman, London, pp. 172-174.

[4] Hagedorn, D. J. (1984). Compendium of pea disases. University of Wisconsin-Madison.

[5] Mart, D., Türkeri, M., Yücel, D. (2018). Peas (Pisum sativum L.) Working Breeding and Registered Pea in Çukurova Conditions, Turkey 8. Seed Production Congress, Niğde, 10-13 September, 2018.

[6] Mart, D., Karaköy, T., Türkeri, M., Yücel, D., Akkaya, M., Yücel, H. (2015). Evaluation of Local Pea (Pisum Sativum L.) Varieties and Lines Collected from Different Regions of Turkey in terms of Yield and Quality in Çukurova Region, Türkiye XI. FieldCrops, Çanakkale-Turkey, 19-23 September, 2015.

[7] Mart, D. (2014). Evaluation of Local Pea (pisum sativum) Varieties and Lines in the Çukurova Region in of Yield Terms and Quality Criteria, 5.Seeds congress, 19-23 October 2014, Diyarbakır-Turkey, (Poster)

[8] Anonymous, 2021. FAO. https:// www. fao. org/ faostat/. 
[9] Eser, D., Avcıŏlu, R., Soya, H., Geçit, H. H., Çiftçi, C. Y., Emeklier, H. Y. (1990). Food Legume and Forage Production and Problems in Turkey. Turkey Agricultural Engineering 3rd Technical Congress, 8-10 January, Ankara-Turkey.

[10] Auld, D. L., Dittterline, R. L., Murray, G. A., Swensen, J. B. (1983). Screening Peas for Winter hardiness under Fieldand Laboratory Conditions. CropSci., 23: 85-88.

[11] Reddy, P. S. (1988). Genetics, Breeding and Varieties. In: Reddy P.S. (ed.), Groundnut. Publication and Information Division, Indian Council of Agricultural Research, Krishi Anusondhan Bhavan, Pusa, New Delhi, pp. 200-317.

[12] Keneni, G., Jarso, M., Wolabu, T., ve Dino, G. (2005). Extent and pattern of genetic diversity for morpho-agronomic traits in Ethiopian highland pulse landraces: I. Field pea (Pisum sativum L.). Genetic Resources and Crop Evolution, (2005)52: 539-549.

[13] Anlarsal, A., E., Yücel, C. ve Özveren, D. (2001). A Study on the Adaptation and Yields of Some Pea (Pisum sativum ssp. Sativum L. and Pisum sativum ssp. Arvense L.) Lines in Çukurova Conditions, Çukurova. Ü. A. F. Journal, 2001, 16(3): 11-20.

[14] Türkeri, M., Mart, D., Karaköy, T., Yücel, D. (2015). Evaluation of Some Pea (Pisum Sativum L.) Genotypes in Terms of Seed Yield and Yield Components in Cukurova Conditions, Turkey XI. Field Crops Congress, Canakkale, 19-23 September, 2015.

[15] Öz, M. ve Karasu, A. (2010). Determination of Seed Yield and Yield Components of Some Pea (Pisum sativum L) Varieties, Süleyman Demirel University, Faculty of the Agriculture Journal, 5 (1): 44-49, 2010.

[16] Bilgili, U., Ve Açıkgöz, E. (1999). Investigations on Important Morphological and Agricultural Characteristics of Near Isogenic Feed Pea Lines with Different Leaf Characteristics. Turkey 3. Field Crops Congress, 15-18 November 1999, Cilt III, Pasture Forage Crops ve Food Grain Legumes (Oral), pp. 96-101, Adana-Turkey.

[17] Gül, İ., et al. (2005). Heritability and Correlation Studies in Pea (Pisumarvense L.) Lines, Asian Journal of Plant Sciences, 4(2): 154-158, 2005.

[18] Ceyhan, E., Önder, M. (2001). Effects of Different Sowing Times on Grain Yield and Some Agronomic Characters of Pea (Pisumsativum L.) Varieties Selçuk Üni. Faculty of Agricultural Publications, Number: 15(25): 159-171.

[19] Akça, A. Mart D., Horuz S, Aysan Y. (2018). Determination of Bacterial Blight Disease Reactions in Different Local Pea Lines in Turkey, Ege Journal of Agricultural Research (EJAR).

[20] Karayel, R. ve Bozoğlu, H. (2008). Agronomic Characteristics of the Local Pea Population Collected from Different Regions of Turkey. Samsun Faculty of Agricultural Publications, 2008, 23(1): 32-38.

[21] Yılmaz N., Kılınç, H. V. (2017). Determination of physiological and morphological characterization of local pea (Pisum sativum L.) populations growing in Giresun province; Akademik Agricultural Journal, 6(2): 141-152.

[22] Bourion, V., Lejeune-Henaut, I., Munier-Jolain, N., Salon, C. (2003). Cold Acclimation of Winter and Sring Peas: Carbon Partitioning as Affected by Light Intensty. E.J. Agronomy: 1-14.

[23] Chahal, G. S. and Gosal, S. S. (2002). Principle sand procedures plant breeding: biotechnologiacal and conventional approaches. Narosa Publishing House, New Delhi. 